\title{
KECERDASAN VISUAL-SPASIAL, KEMAMPUAN NUMERIK, DAN PRESTASI BELAJAR MATEMATIKA
}

\author{
MAMAN ACHDIYAT \\ mamanachdiyat9@gmail.com \\ Program Studi Pendidikan Matematika \\ Fakultas Teknik Matematika dan IPA Universitas Indraprasta PGRI \\ RIDO UTOMO \\ Program Studi Pendidikan Matematika \\ Fakultas Teknik Matematika dan IPA Universitas Indraprasta PGRI
}

\begin{abstract}
Abstrak. Penelitian ini menggunakan metode survey bertujuanuntuk mengetahui pengaruh kecerdasan visual-spasial dan kemampuan numerik terhadap prestasi belajar matematika, pada peserta didik kelas VIII SMP PGRI di Kecamatan Tenjolaya. Teknik pengambilan sampel dengan random sampling terhadap 111 sampel. Teknik pengumpulan data berupa pemberian tes 25 butir soal kecerdasan visual-spasial dan 30 butir soal kemampuan numerik dalam bentuk pilihan ganda, sedangkan data prestasi belajar matematika diambil dari nilai ulangan kenaikan kelas (UKK). Sebelum melakukan uji hipotesis dilakukan uji validitas butir soal untuk tes kecerdasan visual-spasial dan tes kemampuan numerikyang diuji menggunkan korelasi point biserial. Hasil perhitungan normalitas data menggunakan chi-kuadrat dinyatakan normal. Pengujian hipotesis statistik dengan uji $t$ dan uji F.Hasil penelitian menunjukan bahwa terdapat pengaruh yang signifikan antara kecerdasan visual-spasial dan kemampuan numeriksecara bersama-sama terhadap prestasi belajar matematika.
\end{abstract}

Kata Kunci: Kecerdasan Visual-Spasial, Kemampuan Numerik, Prestasi Belajar Matematika

\begin{abstract}
This research uses survey method aimed to know the influence of visual-spatial intelligence and numerical ability on mathematics learning achievement, in class VIII students of PGRI Junior High School in Tenjolaya Subdistrict. Sampling technique with random sampling to 111 samples. Technique of collecting data 25-point test of visualspatial intelligence and 30 items about numerical ability in multiple choice, while mathematics learning achievement data is taken from grade repetition value (UKK). Before performing the hypothesis test, the validity test item for visual-spatial intelligence test and numerical ability test were tested using biserial point correlation. The calculation result of normality of data using chi-square mean otherwise. Testing of statistical hypothesis with t-test and F-test. The result of research shows that there is a significant influence between visual-spatial intelligence and numerical ability together to the achievement of learning mathematics
\end{abstract}

Keywords: Visual-Spatial Intelligence, Numerical Ability, Mathematics Learning Achievement

\section{PENDAHULUAN}

Pendidikan merupakan kebutuhan dasar manusia dalam kehidupan. Pendidikan dipandang sebagai proses yang sangat bermanfaat bagi manusia dalam menjalani kehidupan. Pendidikan juga memegang peranan penting untuk mempersiapkan sumber daya manusia yang berkualitas. Menurut Rabab'h dan Arsaythamby (2015:1) “the 
educational system is primarily viewed as a significant factor forming the basis of an individual's development and progress, and in turn, form the core of counties' development". Pendidikan merupakan faktor utama yang membentuk dasar perkembangan dan kemajuan individu, yang pada akhirnya akan menjadi inti dari pembangunan sebuah bangsa. Sejalan dengan itu, menurut Fadillah (2012: 53) "pendidikan memiliki peranan yang sangat menentukan bagi perkembangan dan perwujudan diri individu, terutama bagi perkembangan bangsa dan negara".

Pendidikan yang baik akan menciptakan sumber daya manusia yang memiliki kompetensi tinggi, cakap, dan terampil. Di Indonesia pendidikan merupakan kegiatan utama yang dilakukan untuk menciptakan generasi masa depan yang unggul dan bermutu. Hal tersebut sejalan dengan fungsi dan tujuan pendidikan nasional yang tercantum pada Pasal 3, UU No. 20 Tahun 2003 tentang sistem pendidikan nasional:

"Pendidikan nasional berfungsi mengembangkan kemampuan danmembentuk watak serta peradaban bangsa yang bermartabat dalam rangka mencerdaskan kehidupan bangsa, bertujuan untuk berkembangnya potensi peserta didik agar menjadi manusia yang beriman dan bertakwa kepada Tuhan Yang Maha Esa, berakhlak mulia, sehat, berilmu, cakap, kreatif, mandiri, dan menjadi warga negara yang demokratis serta bertanggung jawab".

Salah satu yang menjadi ukuran utama keberhasilan pendidikan adalah prestasi belajar yang dicapai pada bidang studi matematika.Pentingnya pelajaran matematika telah diungkapkan oleh banyak literatur penelitian. Menurut Drew (dalam Rabab'h dan Arsaythamby, 2015:1) "mathematics is the most important factor that relates to an individual success". Matematika menjadi faktor yang sangat penting berkaitan dengan sukses seseorang.Banyak bidang pekerjaan dan profesi yang menuntut pelakunya untuk menguasai matematika.Hal tersebut menurut Ajayi dkk. (2013: 202) "mathematics has been highly rated among other subjects an for that reason, it has been described as the queen of all sciences and servant to all discipline".Pentingnya matematika dalam kehidupan menjadi alasan mengapa matematika mendapat penilaian lebih tinggi dibandingkan dengan bidang studi lainnya.Matematika juga disebut sebagai ratu dari semua ilmu pengetahuan dan pelayan bagi semua disiplin ilmu.

Secara umum, hasil pembelajaran matematika peserta didik di Indonesia masih jauh dari harapan, walaupun untuk perseorangan prestasi belajarnya mampu mencapai taraf optimal.Kesenjangan yang sedemikian besar tersebut perlu diperbaiki sehingga setiap peserta didik dapat meningkatkan prestasi belajarnya. Menurut laporan The Third International Mathematics and Science Study (TIMSS) pada tahun 2011, dari 45 negara, prestasi belajar matematika di Indonesia berada di posisi 38. Posisi tersebut turun dua peringkat dari tahun 2007 dimana Indonesia menempati peringkat 36 dari 49 negara.

Banyak faktor yang memengaruhi prestasi matematika peserta didik di Indonesia masih rendah.Faktor eksternal meliputi rendahnya sarana fisik, mahalnya biaya pendidikan, kualitas guru yang tidak merata, dan tidak meratanya akses terhadap pendidikan.Akan tetapi, pegaruh terbesar tetap berasal dari dalam diri pribadi peserta didik. Faktor tersebut terdiri dari faktor fisiologi yang berkaitan dengan kondisi fisik dan faktor psikologis yaitu hal-hal yang berkaitan dengan kondisi jiwa perseta didik.

Faktor internal yang berperan menentukan prestasi peserta didik dalam menempuh pendidikan salah satunya adalah potensi akademik.Potensi akademik memiliki banyak persamaan dengan kecerdasan apabila dilhat dari komponen-komponen penyusunnya. Menurut Gardner (dalam Masykur dan Abdul, 2008:16; Yaumi, 2012: 12) terdapat delapan jenis multiple intelligence atau kecerdasan majemuk, yaitu (1) kecerdasan verballinguistik, (2) logis-matematis, (3) visual-spasial, (4) musik, (5) kinestesis, (6) interpersonal, (7) intrapersonal, dan (8) naturalistik. 
Salah satu jenis kecerdasan yang mempunyai peranan terhadap prestasi peserta didik adalah kecerdasan visual-spasial. Menurut Safaria (2010: 18) kecerdasan visualspasial akan menunjukan kemampuan peserta didik dalam memahami perspektif ruang dan dimensi. Kecerdasan visual-spasial membantu peserta didik memahami konsep abstrak, meliputi persepsi spasial yang melibatkan hubungan spasial termasuk orientasi sampai pada kemampuan yang rumit yang melibatkan manipulasi serta rotasi mental.Dalam kecerdasan visual-spasial diperlukan adanya pemahaman kiri kanan, pemahaman perspektif, bentuk-bentuk geometris, menghubungkan konsep spasial dengan angka dan kemampuan dalam transformasi mental dari bayangan visual.Pemahaman tersebut sangat diperlukan ketika belajar matematika. Menurut Shermann (dalam Tambunan, 2006: 28) berpikir spasial mempunyai korelasi yang positif pada anak usia sekolah, baik pada kemampuan spasial taraf rendah maupun taraf tinggi.

Selain kecerdasan visual-spasial, salah satu faktor lain yang berpengaruh dalam pencapaian prestasi belajar matematika yaitu kemampuan numerik. Peserta didik akan mengalami kesulitan dalam belajar matematika apabila tidak mempunyai kemampuan numerik yang mencukupi. Pauli (dalam Indrawati, 2013: 218) menyatakan bahwa kemampuan numerik akan membantu pemahaman dan nalar peserta didik dibidang yang berkaitan dengan angka-angka.

Adapun tujuan penelitian ini adalah untuk mengkaji pengaruh Kecerdasan VisualSpasial dan Kemampuan Numerik terhadap Prestasi Belajar Matematika".

\section{TINJAUAN PUSTAKA \\ Prestasi Belajar}

Prestasi belajar adalah sebuah kalimat yang terdiri atas dua kata yaitu, "prestasi" dan "belajar" yang memiliki arti yang berbeda. Oleh karenanya untuk memahami lebih mendalam mengenai makna prestasi belajar akan dibahas dulu pengertian "prestasi" dan "belajar". Ditinjau dari segi aspek perubahan yang ingin dicapai, prestasi belajar menurut Sudjana (2011:45) menyatakan bahwa: "Prestasi belajar adalah kemampuan yang dimiliki siswa setelah ia menerima pengalaman belajarnya. Prestasi belajar mempunyai peranan penting dalam proses pembelajaran. Proses penilaian terhadap prestasi belajar dapat memberikan informasi kepada guru tentang kemajuan siswa dalam upaya mencapai tujuan - tujuan belajarnya melalui kegiatan belajar. Selanjutnya dari informasi tersebut guru dapat menyusun dan membina kegiatan - kegiatan siswa lebih lanjut, baik untuk keseluruhan kelas maupun secara individu. Secara garis besar menurut berdasarkan teori Taksonomi Bloom, prestasi belajar ada tiga macam, yaitu keterampilan dan kebiasaan, pengetahuan dan pengertian, serta sikap dan cita cita yang mencakup pada tiga ranah antara lain: 1) Ranah kognitif, berkenaan dengan kemampuan intelektual yang mencakup pengetahuan, pemahaman, penerapan, analisis, sintesis dan penilaian. 2) Ranah Afektif, berkenaan dengan sikap dan nilai yang mencakup kemampuan untuk menerima, menjawab atau reaksi, menilai, organisasi dan mengkarakterisasi dengan suatu nilai atau kompleks nilai. 3) Ranah Psikomotorik, berkenaan dengan keterampilan motorik, manipulasi benda-benda, dan koordinasi dalam menghubungkan dan mengamati berbagai hal."

\section{Prestasi Belajar Matematika}

Prestasi belajar matematika menurut Ferryansyah (2011: 237) adalah hasil yang telah dicapai setelah melakukan proses pembelajaran matematika. Hal tersebut selaras dengan pendapat Nasution (2007: 150), yang menyatakan bahwa prestasi belajar matematika adalah skor yang mencerminkan penguasaan matematika di sekolah yang telah menempuh proses belajar dan diukur dengan tes. Begitupun menurut Astuti \& 
Leonard (2015) yang mengatakan bahwa: "Prestasi belajar matematika adalah hasil yang diperoleh peserta didik dari proses pembelajaran matematika yaitu meliputi proses perubahan tingkah laku yang menghasilkan perubahan-perubahan dalam pengetahuan terutama penguasaan bahan belajar matematika".

Prestasi belajar matematika mencerminkan tolak ukur sejauh mana pencapaian atau keberhasilan belajar matematika yang diperoleh melalui proses belajar. Suhendri (2013: 179) menyatakan bahwa: "Prestasi belajar matematika adalah puncak dari kegiatan belajar yang berupa perubahan dalam bentuk kognitif, afektif, dan psikomotrik dalam hal kemampuan bilangan, bangun, hubungan-hubungan konsep dan logika yang berkesinambungan serta dapat diukur atau diamati."

Hal ini sejalan dengan yang diungkapkan oleh Hartati (2013: 227) yang mengatakan bahwa: "Prestasi belajar matematika adalah hasil akhir yang dimiliki oleh siswa berupa kemampuan-kemampuan dalam menguasai, memahami konsep dalam pelajaran matematika sebagai ilmu tentang logika mengenai bentuk, susunan, besaran dan konsep-konsep yang berhubungan satu sama lainnya yang menggunakan istilah serta didefinisikan dengan cermat, jelas dan akurat untuk membantu manusia dalam memahami dan menguasai kehidupan setelah melalui proses belajar".

Sementara itu, Supardi (2013: 64) mengatakan bahwa prestasi belajar matematika merupakan indikator untuk mengukur keberhasilan siswa dalam proses pembelajaran matematika. Keberhasilan dalam proses pembelajaran merupakan tujuan pengajaran yang diharapkan semua peserta didik. Kegiatan tersebut melibatkan siswa, guru, materi pelajaran, metode pengajaran, kurikulum dan media pembelajaran yang sesuai dengan kebutuhan siswa serta didukung oleh lingkungan belajar-mengajar yang kondusif.

Berdasarkan pendapat beberapa ahli di atas dapat disimpulkan bahwa prestasi belajar matematika adalah tingkat penguasaan siswa terhadap materi pelajaran matematika yang telah diperoleh dari hasil tes belajar dan dinyatakan dalam bentuk skor. Prestasi belajar matematika juga menunjukkan sejauh mana keberhasilan siswa dalam menguasai pelajaran matematika.

\section{Kecerdasan Visual-Spasial}

Menurut Hariwijaya (2005: 14) kemampuan visual-spasial adalah kemampuan seseorang untuk menangkap ruang dengan segala implikasinya.Sejalan dengan hal tersebut, Carter (2010: 28) menyatakan bahwa kecerdasan visual-spasial adalah kemampuan persepsi dan kognitif yang menjadikan seseorang mampu untuk melihat hubungan ruang.Sedangkan menurut Febriana (2015: 14) menyatakan bahwa kecerdasan visual-spasial adalah kemampuan yang berhubungan dengan kemampuan mempresentasi, mentransformasi, dan memanggil kembali informasi simbolis.

Armstrong (dalam Harmony dan Roseli, 2012: 12) menyatakan bahwa kecerdasan visual-spasial merupakan kemampuan menangkap ruang secara tepat. Kecerdasan visualspasial menjadikan seseorang mampu untuk memvisualisasikan gambar, mengenal bentuk dan benda, melakukan perubahan suatu benda dalam pikirannya dan kemudian mewujudkannya dalam visual yang nyata, mengungkapkan data dalam bentuk grafik, dan memiliki kepekaan terhadap keseimbangan, warna, garis, bentuk, dan ruang.

Kecerdasan visual-spasial menjadikan seseorang memiliki kemampuan untuk memahami secara lebih mendalam hubungan antara objek dengan ruang. Menurut Masykur (2007: 108) menyatakan bahwa: "Kecerdasan visual-spasial memiliki ciri-ciri antara lain: (1) Memberikan gambaran spasial visual yang jelas ketika mengerjakan sesuatu; (2) Mudah membaca peta atau diagram; (3) Menggambar sosok orang atau benda mirip dengan aslinya; (4) Sangat menikmati kegiatan visual, seperti teka-teki atau sejenisnya; (5) Mencoret-coret di atas kertas atau buku tugas sekolah; (6) Lebih 
mendalami informasi lewat gambar dari pada kata-kata atau uraian. Siswa yang memiliki kecerdasan visual-spasial yang baik akan lebih mudah belajar degan gambar-gambar visual". Mereka lebih mampu menyerap pembelajaran jika disajikan dengan bantuan benda-benda visual.

Berdasarkan uraian pendapat para ahli di atas dapat disimpulkan bahwa kecerdasan visual-spasial adalah kemampuan dalam melihat hubungan ruang, mempresentasikan, mentransfomasikan, dan memanggil kembali informasi simbolik serta kemampuan untuk menggambarkan sesuatu yang ada dalam pikiran kemudian mewujudkannya dalam bentuk nyata.

\section{Kemampuan Numerik}

Robbins (2006: 53) menyatakan bahwa kemampuan numerik merupakan salah satu dari lima dimensi yang menyusun kemampuan intelektual. Kemampuan numerik adalah kemampuan untuk melakukan pehitungan dengan cepat dan tepat.Sedangkan menurut Sasanguie dkk. (2012: 353) menyatakan bahwa "The ability to represent number has been considered to be a key precursor of children'smathematical development". Kemampuan merepresentasikan angka-angka (numerik) menjadi syarat utama peserta didik dalam mengembangkan kemampuan matematikanya.

Ann (Olatoye dan Aderogba, 2011: 432) menyatakan bahwa kemampuan numerik adalah keahlian seseorang memanipulasi dan menggunakan angka untuk menyelesaikan permasalahan.Menurut Barret dan William (2000:67) kemampuan numerik adalah kemampuan berfikir dengan bilangan-bilangan (angka).Sejalan dengan hal tersebut, menurut Dandy (Indrawati, 2013) bahwa: "Kemampuan numerik adalah kemampuan dalam hal hitungan angka-angka untuk mengetahui seberapa baik seseorang dapat memahami ide-ide dan konsep-konsep yang dinyatakan dalam bentuk angka serta seberapa mudah seseorang dapat berfikir dan menyelesaikan masalah dengan angkaangka."

Kemampuan numerik sebagai kemampuan dasar tentang bilangan, tentunya merupakan faktor yang sangat diperlukan dalam mempelajari matematika serta dalam kehidupan sehari-hari. Seperti pendapat Yuliani (2014: 28), bahwa "kemampuan numerik memiliki peranan yang sangat penting untuk mengatasi permasalahan yang terjadi dalam kehidupan sehari-hari". Menurut Gultom (2001: 24) menyatakan bahwa: "kemampuan numerik disebut juga kemampuan berhitung, yaitu kemampuan matematis yang di dalamnya termuat kemampuan melakukan pengerjaan-pengerjaan hitung seperti menjumlah, mengurangkan, mengali dan membagi, memangkatkan, menarik akar, menarik logaritma, serta memanipulasi bilangan-bilangan dan lambing-lambang matematika".

Berdasarkan pendapat di atas kemampuan numerik adalah tes yang berkaitan dengan kecermatan dan kecepatan dalam penggunaan fungsi-fungsi hitung dasar .Jika dipadukan dengan kemampuan mengingat, maka tes ini dapat mengungkap kemampuan intelektual seseorang terutama kemampuan penalaran berhitung dan berfikir secara logis. Hal lain yang akan terlihat juga adalah kemampuan kuantitatif, ketelitian, dan keakuratan individu dalam mengerjakan sesuatu. Ingatan akan pengetahuan yang sudah pernah dipelajari dibangku sekolah pun turut berperan saat individu menyelesaikan soalnya. Indikator kemampuan numerik dalam hal ini ada tiga materi dalam matematika yaitu aljabar, aritmatika, dan deret.

\section{METODE}

Dalam penelitian ini metode yang digunakan adalah metode survei dengan Teknik pengambilan sampling Probability Sampling yaitu teknik pengambilan sampel yang 
memberikan peluang sama bagi setap anggota (unsur) populasi untuk dipilih menjadi anggota sampel. Adapun Desain penelitian adalah sebagai berikut:

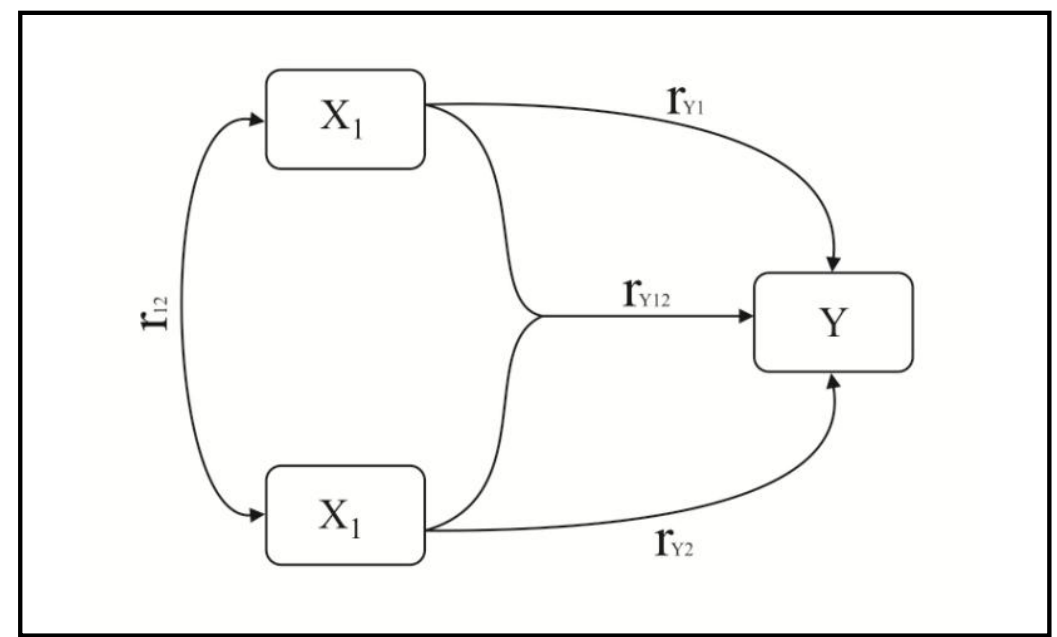

Sumber: Supardi (2013: 191)

Gambar 1 Desain Penelitian

Keterangan :

$\mathrm{X}_{1}=$ Kecerdasan visual-spasial

$\mathrm{X}_{2}=$ Kemampuan numerik

$\mathrm{Y}=$ Prestasi belajar matematika

$\mathrm{r}_{\mathrm{Y} 1}=$ Koefisien korelasi $\mathrm{Y}$ atas $\mathrm{X}_{1}$

$\mathrm{r}_{\mathrm{Y} 2}=$ Koefisien korelasi $\mathrm{Y}$ atas $\mathrm{X}_{2}$

$\mathrm{r}_{\mathrm{Y} 12}=$ Koefisien korelasi $\mathrm{Y}$ atas $\mathrm{X}_{1}$ dan $\mathrm{X}_{2}$

\section{HASIL PENELITIAN DAN PEMBAHASAN}

\section{Hasil Penelitian}

Tabel 1. Tabel Penolong Perhitungan Koefisien Korelasi

\begin{tabular}{|c|c|c|c|c|c|c|c|c|}
\hline$X_{1}$ & $X_{2}$ & $\mathrm{Y}$ & $X_{1}^{2}$ & $X_{2}{ }^{2}$ & $\mathrm{Y}^{2}$ & $\mathrm{X}_{1} \mathrm{Y}$ & $\mathrm{X}_{2} \mathrm{Y}$ & $\mathrm{X}_{1} \mathrm{X}_{2}$ \\
\hline$\Sigma \quad 5840$ & 6366,67 & 4438 & 347808 & 388222,22 & 185956 & 240216 & 259786,67 & 342906,67 \\
\hline
\end{tabular}

\section{Koefisien Korelasi Ganda}

Hipotesis penelitian

$\mathrm{H}_{0}: \mathrm{r}_{\mathrm{Y} 12}=0$ (tidak terdapat hubungan antara kecerdasan visual-spasial dan kemampuan numerik secara bersama-sama dengan prestasi belajar matematika siswa)

$\mathrm{H}_{1}: \mathrm{r}_{\mathrm{Y} 12} \neq 0$ (terdapat hubungan antara kecerdasan visual-spasial dan kemampuan numerik secara bersama-sama dengan prestasi belajar matematika siswa)

Koefisien korelasi dihitung menggunakan rumus Korelasi Product Moment (Pearson) sebagai berikut:

$$
R_{Y 12}=\sqrt{\frac{r_{y 1}^{2}+r_{y 2}^{2}-2 r_{y 1} r_{y 2} r_{12}}{1-r_{12}^{2}}}
$$




$$
\begin{aligned}
& R_{Y 12}=\sqrt{\frac{(0,36)^{2}+(0,37)^{2}-2(0,36)(0,37)(0,26)}{1-(0,26)^{2}}} \\
& R_{Y 12}=0,460
\end{aligned}
$$

Karena nilai $r_{Y 12} \neq 0$ yaitu 0,460 maka tolak $\mathrm{H}_{0}$ yang diartikan terdapat hubungan antara kecerdasan visual-spasial dan kemampuan numerik secara bersama-sama terhadap prestasi belajar matematika peserta didik.

\section{Koefisien Determinasi Ganda $Y$ atas $X_{1}$ dan $X_{2}$}

Dari nilai koefisien korelasi ganda $\mathrm{X}_{1}$ dan $\mathrm{X}_{2}$ terhadap $\mathrm{Y}$ sebesar 0,46 dapat dihitung koefisien determinasi dengan rumus :

$$
\begin{aligned}
K D & =r_{y 12}{ }^{2} \times 100 \% \\
& =0,46^{2} \times 100 \% \\
& =21,16 \%
\end{aligned}
$$

Artinya kontribusi kemampuan penalaran matematika dan kecerdasan visual-spasial secara bersama - sama terhadap prestasi belajar matematika sebesar $21,16 \%$ sedangkan $78,84 \%$ ditentukan oleh faktor (variabel) lain.

\begin{tabular}{|c|c|c|c|c|c|c|c|c|c|}
\hline & $\mathrm{X}_{1}$ & $X_{2}$ & Y & $\mathrm{X}_{1}^{2}$ & $X_{2}^{2}$ & $Y^{2}$ & $\mathrm{X}_{1} \mathrm{Y}$ & $\mathrm{X}_{2} \mathrm{Y}$ & $\mathrm{X}_{1} \mathrm{X}_{2}$ \\
\hline$\sum$ & 584 & 6366,6 & 443 & 34780 & 388222,2 & 18595 & 24021 & 259786,6 & 342906,6 \\
\hline
\end{tabular}

\section{Analisis Regresi Ganda}

Langkah-langkah persamaan regresi ganda dapat di bantu dengan tabel penolong deskripsi data sebagai berikut:

Tabel 2. Tabel Penolong Perhitungan Analisis Regresi Ganda

Sumber : data diolah

Persamaan umum regresi ganda dengan dua variabel bebas dan satu variabel tidak bebas sebagai berikut :

$\hat{\mathrm{Y}}=\mathrm{a}+\mathrm{b}_{1} \mathrm{X}_{1}+\mathrm{b}_{2} \mathrm{X}_{2}$

$\hat{Y}=20,19+0,18 X_{1}+0,18 X_{2}$

Artinya setiap penambahan 1 poin variabel $X_{1}$ akan memambahkan sebesar 0,18 poin variabel $Y$ dan setiap penambahan 1 poin variabel $X_{2}$ akan menambahkan sebesar 0,18 poin variabel $\mathrm{Y}$.

$F_{h}=\frac{R J K_{\text {reg }}}{R J k_{\text {res }}}$

$=\frac{1076,03}{58,93}=18,26$

$\mathrm{F}_{\text {tabel }}$ ditentukan dari tabel distribusi $\mathrm{F}$ untuk $\alpha=0,05$ serta $\mathrm{dk}_{\text {pembilang }}=\mathrm{k}=2 \mathrm{dan} \mathrm{dk}_{\text {penyebut }}$ $=\mathrm{n}-\mathrm{k}-1=108$

Diperoleh $\mathrm{F}_{\text {tabel }}(0,05 ; 2 ; 108)=3,08$

Hipotesis yang diuji, yaitu :

$\mathrm{H}_{0}: \beta_{1}=\beta_{2}=0$ (regresi ganda $\mathrm{Y}$ atas $\mathrm{X}_{1}$ dan $\mathrm{X}_{2}$ tidak signifikan)

$\mathrm{H}_{0}: \beta_{1}=\beta_{2} \neq 0$ (regresi ganda $\mathrm{Y}$ atas $\mathrm{X}_{1}$ dan $\mathrm{X}_{2}$ signifikan)

Karena nilai $F_{\text {hitung }}>F_{\text {tabel }}(18,26>3,08)$ maka $\mathrm{H}_{0}$ ditolak, sehingga dapat disimpulkan terdapat pengaruh signifikan kecerdasan visual-spasial dan kemampuan numerik secara bersama-sama terhadap prestasi belajar matematika. 


\section{Uji Lanjut}

Menentukan $t_{\text {hitung }}$ untuk masing-masing koefisien regresi

$t_{\text {hitung }}$ untuk koefisien regresi $b_{1}$

$t_{b_{1}=\frac{b_{1}}{s_{b_{1}}}}$

$=\frac{0,18}{0,039}=4,62$

$t_{\text {hitung }}$ untuk koefisien regresi $\mathrm{b}_{2}$

$t_{b_{2}=\frac{b_{2}}{s_{b_{2}}}}$

$=\frac{0,18}{0,052}=3,46$

Dengan taraf signifikan $\alpha=0,05$ dan $\mathrm{dk}=\mathrm{n}-\mathrm{k}-1=108$ untuk uji dua pihak diperoleh $t_{\text {tabel }}=1,98$

Dari hasil diatas ternyata $t_{\text {hitung }}>t_{\text {tabel }}$ yaitu4,62>1,98sehingga $H_{0}$ ditolak.Disimpulkan bahwa terdapat pengaruh yang signifikan kecerdasan visual-spasial terhadap prestasi belajar matematika.

Dari hasil diatas ternyata 3,46>1,98 maka $\mathrm{H}_{0}$ ditolak, sehingga dapat disimpulkan terdapat pengaruh yang signifikan kemampuan numerik terhadap prestasi belajar matematika.

\section{Pembahasan}

Pengaruh Kecerdasan Visual-spasial dan Kemampuan Numerik Terhadap Prestasi Belajar Matematika

Dari hasil analisa data prestasi belajar matematika (Y) terhadap 111responden diperoleh data nilai maksimum adalah 58 dan data nilai minimum adalah 22 dengan rincian rentang data 26, banyak kelas 8, dan panjang kelas 5.Setelah dilakukan perhitungan distribusi frekuensi diperoleh nilai rata-rata 40,17, nilai tengah 39,93, dan nilai yang paling sering muncul adalah 39,63. Simpangan baku dari data prestasi belajar matematika sebesar 8,84. Nilai tersebut lebih kecil dibandingkan dengan simpangan baku variabel lainnya, hal tersebut menunjukan bahwa sebaran data prestasi belajar matematika cenderung kurang variatif atau homogen.

Dari hasil perhitungan data kecerdasan visual-spasial $\left(\mathrm{X}_{1}\right)$ terhadap 111responden diperoleh nilai maksimum adalah 94 dan nilai minimum adalah 8 dengan rincian rentang data 86 , banyak kelas 8 , dan panjang kelas 11 , setelah dilakukan perhitungan distribusi frekuensi diperoleh nilai rata-rata 52,84, nilai tengah 55,10, dan nilai yang paling sering muncul adalah 58,83. Simpangan baku dari data kecerdasan visual-spasial tersebut sebesar 19,40 .

Dari hasil perhitungan datakemampuan numerik $\left(\mathrm{X}_{2}\right)$ terhadap 111responden diperoleh nilai maksimum adalah 90 dan nilai minimum adalah 20 dengan rincian rentang data 70, banyak kelas 8, dan panjang kelas 9. Setelah dilakukan perhitungan distribusi frekuensi diperoleh nilai rata-rata 58,14, nilai tengah 59,07, dan nilai yang paling sering muncul adalah 59,64. Simpangan baku dari data kemampuan numerik tersebut sebesar 15,02 .

Berdasarkan data dan analisis dari penelitian yang dilakukan diperoleh hasil korelasi ganda antara variabel kecerdasan visual-spasial $\left(\mathrm{X}_{1}\right)$ dan kemampuan numerik $\left(\mathrm{X}_{2}\right)$ secara bersama-sama terhadap prestasi belajar matematika $(\mathrm{Y})$ yaitu 0,46 . Besarnya koefisien determinasitersebut adalah 0,2116 sehingga dapat diketahui bahwa kecerdasan visual-spasial $\left(\mathrm{X}_{1}\right)$ dan kemampuan numerik $\left(\mathrm{X}_{2}\right)$ memberikan pengaruh terhadap prestasi belajar matematika (Y) sebesar 21,16\%. Artinya ada sebesar 21,16\% prestasi belajar 
matematika dapat dipengaruhi oleh variabel kecerdasan visual-spasial dan kemampuan numeriksecara bersama-sama, Sisanya 78,84\% dipengaruhi oleh faktor lain,

Persamaan regresi ganda pada penelitian ini adalah $\hat{Y}=20,19+0,18 X_{1}+0,18 X_{2}$. Artinya bahwa kecerdasan visual-spasial dan kemampuan numerik pada peserta didik secara bersama-sama akan memberikan kenaikan yaitu sebesar 0,18 untuk variabel $\mathrm{X}_{1}$ dan 0,18 untuk variabel $\mathrm{X}_{2}$ terhadap variabel Y.Setelah dilakukan uji signifikan regresi ganda memakai uji $\mathrm{F}$ dengan membandingkan antara nilai $\mathrm{F}_{\text {hitung }}$ dengan nilai $\mathrm{F}_{\text {tabel }}$, diperoleh nilai $F_{\text {hitung }}$ adalah18,26 sedangkan nilai $F_{\text {tabel }}$ adalah 3,08 .Nilai $F_{\text {hitung }}(18,26)>$ $\mathrm{F}_{\text {tabel }}(3,08)$,sehingga dinyatakan $\mathrm{H}_{0}$ ditolak.Disimpulkan bahwa terdapat pengaruh yang signifikan antara kecerdasan visual-spasial $\left(\mathrm{X}_{1}\right)$ dan kemampuan numerik $\left(\mathrm{X}_{2}\right)$ secara bersama-sama terhadap prestasi belajar matematika $(\mathrm{Y})$.

\section{Pengaruh Kecerdasan Visual-spasial Terhadap Prestasi Belajar Matematika}

Berdasarkan data dan analisis yang dilakukan diperoleh hasil korelasi antara variabel kecerdasan visual-spasial $\left(\mathrm{X}_{1}\right)$ terhadap prestasi belajar matematika $(\mathrm{Y})$ yaitu sebesar 0,36, Besarnya koefisien determinasi tersebut adalah 0,1296 sehingga kecerdasan visual-spasial memberikan pengaruh yang cukup signifikan terhadap prestasi belajar matematika sebesar $12,96 \%$, Artinya $12,96 \%$ prestasi belajar matematika dipengaruhi oleh variabel kecerdasan visual-spasial, Sisanya $87,04 \%$ dipengaruhi oleh faktor lain.

Persamaan regresi pada penelitian ini adalah $\hat{Y}=31,04+0,17 X$, Berarti bahwa setiap peningkatan 1 data kecerdasan visual-spasial akan memberikan kenaikan sebesar 0,17 terhadap prestasi belajar matematika peserta didik. Setelah melakukan uji linieritas kecerdasan visual-spasial $\left(\mathrm{X}_{1}\right)$ terhadap prestasi belajar matematika $(\mathrm{Y})$ didapat $\mathrm{F}_{\text {hitung }}<$ $F_{\text {tabel }}$ yaitu1,29<1,67 berarti data berpola linier, sehingga analisis regresi dapat dilanjutkan.

Kemudian dilakukan uji lanjut koefisien regresi parsial memakai uji t dengan membandingkan antara nilai $t_{\text {hitung }}$ dengan nilai $t_{\text {tabel }}$, diperoleh nilai $t_{\text {hitung }}$ adalah 4,62 sedangkan nilai $t_{\text {tabel }}$ adalah 1,98 .Nilait $t_{\text {hitung }}(4,62)>t_{\text {tabel }}(1,98)$ sehingga $H_{0}$ ditolak.Disimpulkan bahwa terdapat pengaruh yang signifikan kecerdasan visual-spasial $\left(\mathrm{X}_{1}\right)$ terhadap prestasi belajar matematika $(\mathrm{Y})$.

Hasil penelitian tersebut relevan dengan penelitian yang dilakukan oleh Muhamad Ghoni Rif'an (2011) bahwa kecerdasan visual-spasial memengaruhi hasil belajar matematika sebesar 69,8\%. Sedangkan Syarif Hidayatulloh(2012) menyatakan bahwa kecerdasan visual-spasial berpengaruh sebesar 38,44\% terhadap prestasi belajar matematika. Penelitian sebelumnya dilakukan oleh Syarif Hidayatulloh ditahun 2012 dengan judul Pengaruh Kecerdasan Visual-Spasial Terhadap Hasil Belajar Matematika Siswa kelas VIII SMPN 2 Trenggalek (Skripsi Sekolah Tinggi Ilmu Agama Negeri Tulungagung). Berdasarkan penelitian tersebut disimpulkan bahwa terdapat pengaruh yang signifikan antara kecerdasan visual-spasial terhadap hasil belajar matematika. Muhamad Ghoni Rif'an ditahun 2011 dengan judul Pengaruh Kemampuan Spasial terhadap Prestasi Belajar Matematika Materi Pokok Dimensi Tiga pada Siswa Kelas X Semester II SMA Negeri 11 Semarang Tahun Pelajaran 2010/2011 (Skripsi Universitas Islam Negeri Walisongo, Semarang). Berdasarkan penelitian tersebut disimpulkan bahwa semakin tinggi kemampuan spasial peserta didik maka prestasi belajar yang dicapai juga akan semakin meningkat. Sehingga terdapat pengaruh positif yang signifikan antara kemampuan visual terhadap prestasi belajar matematika.

\section{Pengaruh Kemampuan Numerik Terhadap Prestasi Belajar Matematika}

Berdasarkan data dan analisis yang dilakukan diperoleh hasil korelasi antara variabel kemampuan numerik $\left(\mathrm{X}_{2}\right)$ terhadap prestasi belajar matematika $(\mathrm{Y})$ yaitu sebesar 
0,37 . Besarnya koefisien determinasi tersebut adalah 0,1369 sehingga kemampuan numerik memberikan pengaruh yang cukup signifikan terhadap prestasi belajar matematika sebesar $13,69 \%$. Artinya $13,69 \%$ prestasi belajar matematika dipengaruhi oleh variabel kemampuan numerik. Sisanya sebesar $86,31 \%$ dipengaruhi oleh faktor lain.

Persamaan regresi pada penelitian ini adalah $\hat{\mathrm{Y}}=26,79+0,23 X$, Berarti bahwa setiap peningkatan 1 Data kemampuan numerik akan memberikan kenaikan sebesar 0,23 terhadap prestasi belajar matematika peserta didik, Setelah melakukan uji linieritas kemampuan numerik $\left(\mathrm{X}_{2}\right)$ terhadap prestasi belajar matematika $(\mathrm{Y})$ didapat $\mathrm{F}_{\text {hitung }}<\mathrm{F}_{\text {tabel }}$ yaitu0,72<1,68 berarti data berpola linier, sehingga analisis regresi dapat dilanjutkan.

Kemudian dilakukan uji lanjut koefisien regresi parsial memakai uji t dengan membandingkan antara nilai $t_{\text {hitung }}$ dengan nilai $t_{\text {tabel }}$, diperoleh nilai $t_{\text {hitung }}$ adalah 3,46 sedangkan nilai $t_{\text {tabel }}$ adalah 1,98.Nilait $t_{\text {hitung }}(3,46)>t_{\text {tabel }}(1,98)$ sehingga $H_{0}$ ditolak. Disimpulkan bahwa terdapat pengaruh yang signifikan kemampuan numerik $\left(\mathrm{X}_{2}\right)$ terhadap prestasi belajar matematika (Y). Hasil penelitian tersebut relevan dengan penelitian yang dilakukan oleh Ernadi (2013) bahwa kemampuan numerik berpengaruh sebesar 70,56\% terhadap prestasi belajar matematika. Penelitian sebelumnya dilakukan oleh Ernadi pada tahun 2013 dengan judul Pengaruh Kemampuan Numerik terhadap Prestasi Belajar Matematika Siswa kelas VIII SMP Pasar Minggu (Skripsi Universitas Indraprasta PGRI). Berdasarkan penelitian tersebut disimpulkan bahwa terdapat pengaruh positif yang signifikan antara kemampuan numerik terhadap prestasi belajar matematika peserta didik.

\section{PENUTUP}

\section{Simpulan}

1. Terdapat pengaruh yang signifikan kecerdasan visual spasial dan kemampuan numerik secara bersama-sama terhadap prestasi belajar matematika. Besarnya pengaruh kecerdasan visual spasial dan kemampuan numerikterhadap prestasi belajar matematika ditunjukkan oleh koefisien determinasi sebesar 21,16\%.

2. Terdapat pengaruh yang signifikan kecerdasan visual spasial terhadap prestasi belajar matematika. Besarnya pengaruh kecerdasan visual spasial terhadap prestasi belajar matematika ditunjukkan oleh koefisien determinasi sebesar 12,96\%.

3. Terdapat pengaruh yang signifikan kemampuan numerik terhadap prestasi belajar matematika. Besarnya pengaruh kemampuan numerikterhadap prestasi belajar matematika ditunjukkan oleh koefisien determinasi sebesar 13,69\%.

\section{Saran}

1. Bagi pihak sekolah, dengan menyadari bahwa mata pelajaran matematika memegang peranan penting bagi setiap peserta didik, sehingga harus lebih memperhatikan potensi kecerdasan visual-spasial dan kemampuan numerik peserta didik. Dengan demikian sekolah mampu mendisain pembelajaran matematika yang sesuai dengan kondisi peserta didik agar dapat meningkatkan prestasi belajar matematika peserta didik sesuai dengan tujuan pembelajaran.

2. Bagi guru, diharapkan dapat memberikan metode pembelajaran yang sesuai dengan potensi kecerdasan visual-spasial yang dimiliki oleh peserta didik dan memberikan laihan untuk meningkatkan kemampuan berhitung peserta didik. Dengan demikian, diharapkan guru akan lebih mudah dalam penyampaian pembelajaran dan prestasi peserta didik pun mengalami peningkatan.

3. Bagi peserta didik, diharapkan untuk mengenali potensi kecerdasan visual spasial yang dimiliki, kemudian berusaha untuk meningkatkan potensi tersebut. Mengasah 
kemampuan numerik yang dimiliki dengan sering mengerjakan latihan soal, sehingga tujuan prestasi belajar yang diharapkan dapat tercapai.

\section{DAFTAR PUSTAKA}

Ajayi, K. O. dkk. 2013. Effects of students' attitude and self-concept on achievement in senior secondary school mathematics in Ogun State, Nigeria. Journal of Research in National Development, 9(2), 202-211.

Armstong, Thomas. 2002. Kinds of Smart Menemukan dan Meningkatkan Kecerdasan Anda Berdasarkan Teori Multiple Inteligence. Jakarta: Gramedia.

Armstong, Thomas. 2013. Kecerdasan Multipel di dalam Kelas. Jakarta: Indeks.

Astuti, A., \& Leonard. 2015. Peran kemampuan komunikasi matematika terhadap prestasi belajar matematika siswa. Jurnal Formatif, 2(2), 102-110. Retrieved from http://journal.lppmunindra.ac.id/index.php/Formatif/article/view/91/88

Barret, Jim dan Geoff William. 2000. Tes Bakat Anda. Jakarta: Gaya Medika Pratama.

Carter, P. 2010. Tes IQ dan Bakat: Menilai Kemampuan Penalaran Verbal, Numerik, dan Spasial Anda, Jakarta: Indeks.

Fadlillah, M. 2012. Desain Pembelajaran PAUD. Yogyakarta: ArRuzzMedia

Febriana, E. 2015. Profil kemampuan spasial siswa menengah pertama (smp) dalam menyelesaikan masalah geometri dimensi tiga ditinjau dari kemampuan matematika. Jurnal Elemen, 1(1), 13-23.

Ferryansyah. 2011. Perbandingan prestasi belajar matematika siswa antara pembelajaran yang disertai penciptaan kondisi dan tanpa disertai penciptaan kondisi alfa. Jurnal Socioscientia, 3(2), 235-242.

Gultom, S. 2001. Model Kognitif untuk Mengubah Bahasa Verbal menjadi Model Matematika. Jakarta: Pelangi Pendidikan.

Hariwijaya, M. 2005. Tes Intelegensi. Yogyakarta: Andi Offset.

Hartati, L. 2013. Pengaruh gaya belajar dan sikap siswa pada pelajaran matematika terhadap hasil belajar matematika. Jurnal Formatif, 3(3), 224-235.

Indrawati, F. 2013. Pengaruh kemampuan numerik dan cara belajar terhadap prestasi belajar matematika. Jurnal Formatif, 3(3), 215-223.

Masykur, M. 2007. Mathematical Intelligence. Yogyakarta: ArRuzz Media.

Masykur, M. \& Abdul Halim Fathoni. 2008. Mathematical Intelligence: Cara Cerdas Melatih Otak dan Menanggulangi Kesulitan Belajar. Yogyakarta: ArRuzz Media.

Nasution, P. 2007. Perbandingan prestasi belajar matematika antara siswa yang menggunakan aturan segitiga dengan aturan jajaran. Majalah Ilmiah Ukhuwah, 2(2). 148-150.

Olatoye, R. A. dan A. A. Aderogba. 2011. Performance of senior secondary school science students in aptitude test: The role of student verbal and numerical abilities. Journal of Emerging Trends in Educational Research and Policy Studies (JETERAPS), 2(6), 431-435.

Robbins, S.P. 2006. Perilaku Organisasi. Jakarta: Indeks

Safaria, Aan T. 2010. Mengembangkan Kecerdasan Anak: Meningkatkan Kemampuan IQ Anak agar Tumbuh Cerdas. Yogyakarta: Pohon Cahaya.

Sasanguie, Delphine dkk. 2012. Association between basic numerical abilities and mathematics achievement. British Journal of Developmental Psychology, 30, 344-357.

Sudjana, N. 2011. Penilaian Hasil Proses Belajar Mengajar. Bandung: Remaja Rosdakarya. 
Suhendri, H. 2011. Pengaruh kecerdasan matematis logis dan kemandirian belajar terhadap hasil belajar matematika. Jurnal Formatif. 1(1), 29-39.

Suhendri, H. 2013. Penerapan model pembelajaran konstruktif berbasis penemuan terbimbing dalam meningkatkan hasil belajar matematika. Jurnal Formatif, 3(3), 177-183.

Supardi, U.S. 2013. Aplikasi Statistika dalam Penelitian. Jakarta: Change Publication.

Undang-Undang No. 20 Tahun 2003 tentang Sistem Pendidikan Nasional.http://sipuu.setkab.go.id/PUUdoc/173839/UU0202013.pdf (diunduh 22 Mei 2016)

Yaumi, M. 2012. Pembelajaran Berbasis Multiple Intelligences. Jakarta: Dian Rakyat

Yuliani, R. 2014. Pengaruh Kemampuan Nnumerik Terhadap Prestasi Belajar Matematika Peserta Didik. Skripsi. Universitas Indraprasta PGRI, Jakarta: Tidak Diterbitkan. 